\title{
Inferiority Embodied: The 'Men-struating' Jew and Pre-Modern Notions of Identity and Difference
}

The generation and tradition of cultural narratives is one of the bases in the process of formation of identity. During the Christian Middle Ages, starting with Augustine's doctrine on the Jews, the so-called "hermeneutical Jew" was fashioned-a figure that assumed distinctive character, bodily characteristics, and narrative significance in Christian thought and culture. ${ }^{1}$ In dealing with the specific traits of this hermeneutical Jew, Christians sought to strengthen their own core beliefs and values, which they thought superior to their Jewish 'Others.' Narratives of Jewish false understanding of the Scripture, of their customs, or of ritual murder were discussed and disputed widely. These narratives convey larger discourses on Jewish hereditary inferiority vis-à-vis Christian spiritual and socio-cultural superiority. Various motifs support these narratives, from the Jew's stubbornness and blindness to uncover the Scripture's true and ultimate meaning, their economic wickedness as usurers and money-lenders, to the repeated claim of Jewish usage of Christian blood for magical practice.

The discourse of Jewish inferiority manifests itself also in a second category of narratives and motifs that focus on the 'Jewish body.' Following Paul's depiction of the Jews as carnal and in sharp contrast to the new and spiritually advanced Christian who could free himself from fleshly desires in his covenant with Christ, the Jews' bodies were claimed to differ fundamentally from the bodies of Christians. They were marked by weakness and pallor, were diseased and distorted, especially with regards to their sex and gender. All of these somatic markers were considered a reflection of the Jews' spiritual impurity and inferiority. Pre-modern narratives and motifs surrounding the 'Jewish body' can be interpreted as transmitting a notion of religious identity and difference that is not solely rooted in culture. Rather, they point to the formation of proto-racial concepts of identity, which equated particular kinds of religious belief with particular kinds of bodies. ${ }^{2}$ One of the motifs in this canon is the "men-struating" 3 Jew-

1 Cf. J. Cohen, Living Letters of the Law: Ideas of the Jew in Medieval Christianity (Berkeley: University of California Press, 1999), 10 -19.

2 This article uses the terms "proto-racial" and "proto-racist" following the example of M. L. Kaplan, Figuring Racism in Medieval Christianity (New York: Oxford University Press, 2019). The terms are used as a delineation from the modern understanding of race and racism often

Ә OpenAccess. (c) 2021 Kerstin Mayerhofer, published by De Gruyter. (cc))BY-NC-ND This work is licensed under the Creative Commons Attribution-NonCommercial-NoDerivatives 4.0 International License. https://doi.org/10.1515/9783110671995-008 
a notion of a regular flow of blood that Jews were considered to be afflicted with, marking their religious, social, and somatic difference.

The motif of Jewish 'male menstruation' was established and shaped during the twelfth and thirteenth century. Until the early sixteenth century, these voices were usually clerical, discussing the very idea of the 'men-struating' Jew. However, already in the fourteenth century, contemporary medical knowledge and scientific findings had brought forth a first somehow 'scientific' discussion of Jewish 'male menstruation.' The 'men-struating' Jew left his purely figurative context and the doctrine of spiritual inferiority embodied in this figure subsequently translated into social and legal spheres. The most prominent example can be found in the establishment of the concept of "purity of blood" ${ }^{4}$ at the Iberian Peninsula. Forced conversions of Jews (and Muslims) in Reconquista Spain took place since the middle of the thirteenth century and intensified in

connected to the history of the trans-Atlantic slave trade and to the notion of biological differences between groups of people. Often times it is considered anachronistic to use the terms "race" and "racism" when dealing with pre-modern sources and histories, based on the claim that the pre-modern understanding of diversity was rooted in culture rather than in nature. In order to avoid this contradiction, the usage of "proto-racial" and "proto-racist" is suitable as it still acknowledges the fact that, indeed, ancient and pre-modern racism is not solely a cultural concept. The present article operates with a definition of racism and race that draws on the creation of a hierarchy between groups as its constitutional element. According to this definition, we can speak of racism and defining races whenever one group represents itself as superior to another group of people. This hierarchy is persistent as is the claim of subordination grounded in it. Other features, however, such as somatic markers or permanence of physiological and cultural traits of identity, might vary. B. Isaac has shown that the defining element of ancient and pre-modern understandings of racial difference, rooted both in religion and nature, however, is the postulation of superiority and inferiority in relation to one another. Cf. B. Isaac, The Invention of Racism in Classical Antiquity (Princeton: Princeton University Press, 2004), 1-52. Proto-racial distinctions can function both with and without biological references and notions about culture and nature do often intersect. According to A. Loomba, religion and theological doctrine, too, have always played a central role in the proto-racist formation of identity based on hierarchy. Cf. A. Loomba, "Race and the Possibilities of Comparative Critique," New Literary History 40, no. 3 (2009): 501-22. Isaac's and Loomba's theories on pre-modern constructions of race and on pre-modern racism and their continuation by Kaplan lie at the core of this article. The same theories apply to gender as a pre-modern category of determination and identity and both categories, race and gender, do strongly intersect in the figure of the 'men-struating' Jew. 3 The term "men-struation" was coined by Gloria Steinem in her famous essay "If Men Could Menstruate," in Outrageous Acts and Everyday Rebellions (New York: New American Library, 1983).

4 Cf. M. Diemling, “'Mit Leib und Seele?’ Überlegungen zum Körperbild jüdischer Konvertiten in der Frühen Neuzeit,” Aschkenas 15, no. 2 (2006): 411. 
the violence of $1391 .^{5}$ The large number of "conversos" or "New Christians," as the Jewish converts were called, led to a belief that Jews were insincere in their conversion, and pressed for a delineation of boundaries between 'Old' and 'New Christians.'

In this article, I trace the Christian concept of Jewish hereditary inferiority mapped onto the Jews' bodies using the example of the 'men-struating' Jew. I demonstrate how religion, physiology, sex, and gender as categories of social determination intersect to create a notion of identity and difference, which can be regarded as proto-racial. To do so, I will scrutinise the image of a bleeding Jewish man with regards to the formation of a larger motif of Jewish 'male menstruation' in sources from the thirteenth to the seventeenth century from theological, medical, and political backgrounds.

\section{What is Jewish 'Male Menstruation'?}

A corpus of texts from the twelfth to the fifteenth century describes a male Jew suffering from a spontaneous and anomalous bleeding that reappears at regular intervals. The bleeding is neither the result of injury nor of a chronic illness. If physiological details are provided, they usually refer to the bleeding's source in the genital or anal region. Most of the sources associate this regular bleeding in Jewish men with menstruation and use a broad vocabulary and imagery to frame this notion. The association itself can be both explicit, by referring back to women or the biological process of menstruation, and implicit, by alluding to religio-cultural understandings of sex and gender.

The term Jewish 'male menstruation' itself was coined by Salo W. Baron (1895-1989). In his magnum opus A Social and Religious History of the Jews, he addressed the account of a 'men-struating' Jew by the Dominican Thomas de Cantimpré (1201-1270/2). ${ }^{6}$ Baron concluded that "few of Thomas' readers doubted the existence of such a Jewish malady often appearing as a sort of

5 Jews on the Iberian Peninsula had experienced compulsory or forced conversions already under Visigothic rule in the fifth century. P. Fredriksen's article in the present volume suggests that a notion of the Jews as an inferior 'race' is already established in Visigothic canon law which had never fully accepted Jewish converts who, as a result, would always rank on a lower legal and social level than "gothic" Christians. Cf. P. Fredriksen, "Divinity, Ethnicity, Identity: 'Religion' as a Political Category in Christian Antiquity,” 101-20 of the present volume. 6 Cf. Thomas Cantipratanus, Bonum Universale De Apibus, ed. G. Colvenere (Douai: Baltazar Beller, 1627), II, 29. 
male menstruation [...]."7 Thomas indeed reports of the spontaneous effusion of blood from a Jew's body that he traces back to a "vein of evildoing," a "congen-

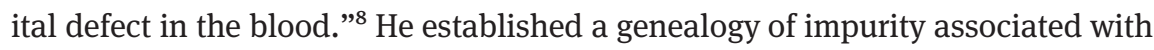
the Jews' alleged responsibility for the killing of Christ. According to Thomas, all Jews are "tormented importunately by this [blood] flow without expiation." 9 The term 'male menstruation,' however, does not appear in the original source. Thomas only speaks of a "macula sanguinis" ("stain of blood") without reference to (female) menstruation.

Other sources provide us with a more distinct image. An anonymous treatise titled Tractatus de locis et statu sancte terre ierosolimitane ${ }^{10}$ mentions a "fluxus sanguinis" in Jewish men, which appears "singulis lunationibus"- "with every [changing of the] moon."11 What the text must have in mind here is indeed female menses, which is linguistically linked both to month (lat. mensis) and moon (gr. mènē). It draws on ancient medical theory that linked the female menstrual cycle with the lunar cycle. ${ }^{12}$ What is especially important with regards to

7 S. W. Baron, A Social and Religious History of the Jews, 2nd rev. ed. (New York: Columbia University Press, 1967), 11:153.

8 M. L. Kaplan, “'His Blood Be on Us and on Our Children': Medieval Theology and the Demise of Jewish Somatic Inferiority in Early Modern England," in The Cultural Politics of Blood, 15001900, ed. K. A. Coles et al. (London: Palgrave Macmillan, 2014), 109.

9 Cited from I. M. Resnick, “Cruentation, Medieval Anti-Jewish Polemic, and Ritual Murder," Antisemitism Studies 3, no. 1 (2019): 104. The Latin original reads: “[...] ex maledictione parentum [referring here to Matt 27:25 and the blood curse] currat adhuc in filios vena facinoris, per macula sanguinis; ut per hanc importune fluidam proles impia inexpiabiliter crucietur, quousque se ream sanguinis Christi recognoscat poenitens, et sanetur," ibid., 120-21.

10 Cf. B. Z. Kedar, "The Tractatus de locis et statu sancte terre ierosolimitane," in The Crusades and Their Sources: Essays Presented to Bernard Hamilton, ed. J. France and W. G. Zajac (Aldershot: Ashgate, 1998), 111-34.

11 "Tractatus de locis," app. 1, De Iudeis: "Quorum primi sunt Judei, homines obstinati, plusquam mulieres imbelles, ubique servi, singulis lunationibus fluxum sanguinis patientes," ed. Kedar, 130. Translation: "Like this, however, are the Jews, obstinate men, unwarlike, even more than women, everywhere servants, with any [rise of the new] moon suffering from a flux of blood." Unless otherwise stated, all translations are mine. Cf. also Jacques de Vitry, Historia Orientalis, 82.160: "Imbelles enim et imbecilles facti sunt quasi mulieres. Unde singulis lunationibus, ut dicitur, fluxum sanguinis patiuntur," ed. Donnadieu, 328. Translation by I. M. Resnick, On Roots of the Myth of Jewish Male Menses in Jacques de Vitry's History of Jerusalem (Ramat Gan: Bar-Ilan-University Press, 1998), 22: "They are unwarlike and weak weak even as women, and it is said that they have a flux of blood every month,"

12 Cf. Isidore of Seville, Etymologiae 11.140: "The menstrual flow is a woman's superfluous blood: it is termed 'menstrual,' menstrua, because of the phase of the light of the moon by which this flow comes about. The moon is called MENE in Greek.” Translation by W. D. Sharpe 
the Tractatus de locis is the fact that this text has generally been considered to the be the oldest mention of Jewish 'male menstruation,' dating roughly to 1170. Even though we encounter the Jewish "fluxus sanguinis" in different varieties in the various sources, the Tractatus de locis and its transmission by Jacques de Vitry, which we shall turn to later, contributed largely to the conceptualisation of the Jewish blood flow as a sort of 'male menstruation,' especially in modern scholarship.

Yet, even when a medieval source uses the term 'menstruation,' we cannot be sure what the authors really wanted to denote with this term. Menstruation as a vaginal discharge, following a fixed cycle during the fertile lifespan of an individual with respective reproductive organs (specifically the uterus and ovaries)-this pragmatic picture is certainly not what the contemporary authors had in mind when attributing some sort of 'menstrual' bleeding to a Jewish man. However, taboos surrounding the biological process of menstruation and the menstrual cycle were important in conveying the meaning of some authors who used the term. ${ }^{13}$ With regards to these issues, throughout this article, the idiom Jewish 'male menstruation' and the 'men-struating' Jew will be applied

in Isidore of Seville: The Medical Writings, ed. W. D. Sharpe (Philadelphia: The American Philosophical Society, 1964), 48.

13 A variety of taboos surround blood and, especially, menstrual blood. The most common misogynist stigmas concerning menstruation are known from Pliny the Elder, "Remarkable Circumstances Connected with the Menstrual Discharge," in Natural History, ch.13, 2151-2. Among other taboos, Pliny claimed sexual intercourse with a woman would produce stillborn, sick, or otherwise monstrous offspring. This notion lies behind commonly known blood taboos in both Jewish and Christian religious law. Both forbid sexual relations with a menstruant and understand menstruation itself as one of the ten curses of Eve. This led to an increased marginalisation of the menstruant regulated in the Mishna and Talmud's Niddah laws, rendering the menstruant unclean and impure for a specific timeframe before, during, and after the bleeding. Church fathers like Jerome perpetuated the Talmudic laws and subsequently banned menstruants from participation on church services. Cf. Jerome, “Against Helvidius," in Saint Jerome: Dogmatic and Polemical Works, vol. 53 of The Fathers of the Church, ed. J. N. Hritzu (Washington: Catholic University of America Press, 1965); Theodore of Canterbury, The Penitential of Theodore and the Iudicia Theodori, ed. T. Charles-Edwards (Cambridge: Cambridge University Press, 1995). Even today, menstrual taboos are exploited as the main causes for the exclusion of women from religious positions of authority in both Judaism and (Catholic) Christianity. In addition, premodern medical texts emphasised the notion of menstruosity, that is, a body's ability to menstruate, in comparison with monstrosity, that is, the production of a defective child. Menstrual blood played a central, yet passive, role in conception and gestation, and any imperfection in a human being was traced back to the defect of menstrual blood and thus, ultimately, to the imperfection the menstruant altogether. Cf. J. Cadden, “Just Like a Woman': Passivity, Defect, and Insatiability,” in Nothing Natural Is Shameful: Sodomy and Science in Late Medieval Europe (Berlin: De Gruyter, 2014), 122-28. 
as technical terms only (and are thus always put in quotation marks). Further technical terms or terminology that has been coined in early modern or modern scholarship (e.g., "biology") without, terminologically, linking to the premodern times, will be marked similarly.

We can understand the various manifestations of Jewish 'male menstruation' in pre-modern sources within the context of literary narrative and as parts of literary motif. A motif as the "minimal thematic unit"14 of a text is characterised by repetitious intratextual and intertextual recurrence. It conveys a larger theme that is mostly abstract and implicit in the more concrete figurative motif. Focusing on the identification and analysis of motifs assists our interpretation of a work as they point to a motivation, intention, or meaning outside of the text itself. For our corpus of sources, the image of a bleeding Jewish man supports the motif of Jewish 'male menstruation.' This, in turn, contributes to the theme of Jewish 'Otherness,' a deviation from Christian normative morality and physicality that manifests itself in the aberration of the 'Jewish' body.

The theme of the 'Jewish body,' in turn, can be interpreted within the narrative context of the individual human body as a symbol for a larger bound unit like a religious or cultural community. ${ }^{15}$ Corporeal images and constructions are useful means for the representation of social or religious values. The Jews are not part of the Christian communal body, which is bound together by rituals and shared hope for salvation. Figuratively, they were represented with lewdness, sickly pallor, timidity, melancholy, and a bleeding ailment, all of which helped to shape the 'Jewish body' which differs significantly from the Christian body. As menstruants were generally believed to be uncontrollable and their bodies unbound, ${ }^{16}$ the hermeneutical 'men-struating' Jew too had to be pushed to the margins of Christian society and could not be a member of a spiritual communal Christian body. Jewish 'male menstruation' thus serves as a marker for alterity and inferiority inscribed into the Jewish body. Lastly, it alludes to many more cultural narratives surrounding the body, gender, and sexuality promoted by the importance of blood. The 'men-struating' Jew crosses two borders alikebetween male and female as well as between Jew and non-Jew. Both Jews and

14 G. Prince, A Dictionary of Narratology (Lincoln: University of Nebraska Press, 2003), 55. 15 Cf. M. Douglas, Purity and Danger: An Analysis of the Concept[s] of Pollution and Taboo (London: Routledge, 2002), 141-59.

16 Cf. e. g. B. Bildhauer, Medieval Blood (Cardiff: University of Wales Press, 2006); idem, "Blood, Jews and Monsters in Medieval Culture," in The Monstrous Middle Ages, ed. B. Bildhauer and R. Millis (Cardiff: University of Wales Press, 2003), 75-97; and idem, "Medieval European Conceptions of Blood: Truth and Human Integrity: Medieval European Conceptions of Blood," Journal of the Royal Anthropological Institute 19 (2013): 57-76. 
women are considered inferior when measured against a discursive and normative image of humankind being Christian and male.

The category of gender is entwined with a proto-racial understanding of difference in the 'men-struating' Jew. Both female menstruation and Jewish 'male menstruation' are considered the result of divine punishment following an original spiritual misdeed or sin. As such, they are transmitted from generation to generation. Their inherited character becomes both congenital, indicated in its 'biology, and genealogical. The 'biological' nature of the bleeding as well as its cultural foundation conflate and result into the idea of spiritual inferiority inscribed in the body. As such they are used as reasoning and reinforcement of social oppression and political discrimination. Jews and women alike could thus not fit into their societal order and had to be subordinate. Motifs like Jewish 'male menstruation' support the legal curtailment of the Jews' social status exerted by both church and secular authorities.

\section{Foundations for and Perceptions of the 'Men-Struating' Jew}

We encounter the 'men-struating' Jew in sources of four different genre groups: sermon collections and exempla, medical texts, natural philosophical treatises, and historiographical and hagiographical material. Representations of Jewish 'male menstruation' are mostly connected to a source's generic intention and use varying imagery. ${ }^{17}$ Terminology, that is, how the motif of Jewish 'male menstruation' is verbalised, too, varies accordingly. Some sources use more implicit terminology and abstract images, as we have encountered in Thomas de Cantimpré's Bonum Universale de Apibus. Other texts use vague vocabulary, albeit evoke clear images when juxtaposing the description of Jews with the image of a weak woman, therein marking a moment of clear feminisation, as, for example, in the Tractatus de Locis. Later sources express the notion of a 'men-struating' Jew more openly and describe Jews as "menstruosi [...] quam mulieres,"18 ("menstruous [...] like women") or claim that "omnes homines

17 This observation is based on S. Gaunt, Gender and Genre in Medieval French Literature (Cambridge: Cambridge University Press, 2009), who argues that genre is inextricably linked with assumptions about gender. The same can be assumed about the representation of the 'men-struating' Jew in our corpus sources.

18 "The Computus Iudaicus of 1342," in Medieval Latin Christian Texts on the Jewish Calendar: A Study with Five Editions and Translations, ed. C. P. E. Nothaft (Leiden: Brill, 2014), 427. 
Iudei ut mulieres menstrua patiuntur"19 ("all Jewish men, like women, suffer from menstruation"). Especially the sources stemming from a more 'scientific' background, medical and natural philosophical treatises alike, established the notion of a permanence of 'Otherness' through the continuity of the body.

All of the sources, including 'scientific' ones, are influenced by contemporary Christian theology and doctrine. The mention of the 'men-struating' Jew is inextricably linked to an exegesis of the so-called "blood curse" from the Gospel of Matthew. The phrase "His blood be on us and on our children," 20 in Matt 27:25, alludes to the Jews' willingness to accept liability for Jesus' death. It is this scriptural passage that serves as foundation for linking the Jew's sinfulness with the symbol of blood-as the Jews had spilled Christ's blood, they were now afflicted with a bleeding from their bodies in return. In referencing those Jews present at the crucifixion, the notion of the hereditary nature of the bleeding as well as of genealogical guilt is emphasised. The understanding of the bleeding as shameful and humiliating is amplified in a subsequent exegesis of Matt 27:25 in reference to Ps 78:66. Many sources cite Ps 78:66 [Vulgate 77:66] and the account of God's punishment of the Philistines with some sort of anal disease verbatim: "et percussit hostes suos retrorsum obprobrium sempiternum dedit eos"-“And he smote his enemies in the hinder parts: he put them to a perpetual reproach.” This passage, in turn, has previously often been read in light of 1 Sam 5:6, and the mentioned disease in Ps 78:66 is often interpreted as bleeding haemorrhoids. ${ }^{21}$ Subsequent varieties of the motif of Jewish 'male menstruation,' evoking images of bleeding haemorrhoids, take their basis in this specific reading of Matt 27:25. Regardless of the number of scriptural passages used as spiritual proof-texts, all sources conclude that Jewish 'male menstruation' is the result of divine punishment in vengeance for the passion of Christ. The bleeding, however it may be specified, is considered congenital and "brought on by the Jews' participation in the crucifixion, as the source of the bleeding disease." ${ }^{22}$ In the further course, it is regarded as the source of the Jews' physical

19 Cecco d'Ascoli, “Cicchi esculani viri clarissimi in Spheram Mundi enarratio," in The Sphere of Sacrobosco and Its Commentators, ed. L. Thorndike (Chicago: University of Chicago Press, 1949), 409.

20 Unless otherwise stated, all English translations are from KJV.

211 Sam 5:6 (KJV): "But the hand of the LORD was heavy upon them of Ashdod, and he destroyed them, and smote them with emerods, even Ashdod and the coasts thereof." While the Hebrew עפלים ('ofalim) simply means something growing where it shouldn't, for example, a lump or a tumour, most passages in the Hebrew Bible using the term are commonly read as referring to haemorrhoids (throughout 1 Sam and in Deut 28:27).

22 Kaplan, “'His Blood Be on Us and on Our Children'," 109. 
weakness, ${ }^{23}$ their sickly pallor, ${ }^{24}$ and specific 'Jewish' ailments such as dysentery and dropsy, all of which are equally shameful.

Images like these underline pre-modern proto-racist notions of difference. Particular faiths are equated with particular somatic attributes and both are associated with distinct moral qualities. While the qualities of faith are hidden inside and unseen, somatic markers help to render them visible. In the case of the 'men-struating' Jew, a discourse of hereditary guilt and genealogical inferiority is embodied in a physiological process that, as such, too, is considered humiliating, shameful, and impure. The repetition of particular motifs and stereotypes reinforced the theme of the Jews as misguided enemies to good Christians. Body-related motifs, such as Jewish 'male menstruation,' aimed at emphasising the Jews' carnality in contrast to the spiritually disembodied Christian. The moment of feminisation, manifested in the equation of the Jewish "fluxus sanguinis" with (female) menstruation also played a key role: the Jewish male appears as uncontrollable and melancholic, unfit to exert his male authority hence subordinate-like women. The 'men-struating' Jew serves as a hermeneutical figure embodying discourses of ungodliness as well as of spiritual and societal inferiority.

In the following, I turn to two pre-modern sources from both a clerical and a medical background. Both of these were known and used widely and had multiple translations and reprints way into the modern times. They promote two different varieties of the motif of Jewish 'male menstruation,' which, as we shall see, resonate largely with their genres. Both sources, however, also help us to understand how various notions surrounding the 'men-struating' Jew, both on a theological and a 'scientific' level, intersected to fit a larger narrative frame and support the proto-racial discourse of hereditary inferiority. Taking a look onto early modern sources from the Iberian Peninsula as a third example will document the translation of this doctrine into social and legal spheres. All of these sources demonstrate how the proto-racial notion of difference manifested in the 'men-struating' Jew is shaped using three ideological mechanisms: (theological) universalisation, ('scientific') naturalisation, and (socio-political) normalisation.

23 Cf. Caesarius Heisterbacensis, Caesarii Heisterbacensis monachi ordinis Cisterciensis dialogus miraculorum, Distinctio Secunda, capitulum XXIII (II: 23), ed. J. Strange (Cologne: Sumptibus J. M. Heberle, 1851), 1:92.

24 Cf. Hugo Cardinalis, Repertorium apostillarum utriusque testamenti domini Hugonis Cardinalis (Basel: Ioannes Amerbachius, Ioannes petri \& Ioannes froben, 1504), 2:187v. 


\section{Universalisation: Jacques de Vitry's History of the East (1216-1221)}

The idea of the 'men-struating' Jew is best known from a mid-thirteenth century source by French Dominican and later Bishop of Acre Jacques de Vitry (c. 1160/ 70 -1240). Jacques de Vitry has been described as "one of the great medieval cultural historians, ${ }^{25}$ and played a crucial role in reporting about the crusades to the Holy Land, as well as on religious trends in Europe. His Abbreviated History of Jerusalem (Historia Hierosolimitana abbreviata) was commissioned by Pope Innocent III aiming at an account of the progress of the Fifth Crusade and an overall historiography of the Holy Land. Originally intended as a tripartite work, Jacques managed to finish only two volumes, the History of the West (Historia Occidentalis) and the History of the East (Historia Orientalis). The widespread dissemination and reception of the History of the East was a response to the large demand for information about the East. In offering detailed descriptions of the foreign lands, peoples, their rituals and wonders, Jacques satisfied his readers' curiosity concerning 'Others.' His work also served a reconfirmation of his readers' own Christian or regional identity, with his "descriptions of deviant rites and doctrines to reaffirm their [sc. the Christian readers'] own identity as orthodox Latin Christians or to compare with domestic heresies against which crusades were often waged." 26

In books HOr 74-83, Jacques deals at length with all different peoples living and dwelling in the Holy Land, starting with the various Christian denominations (HOr 74-81) and concluding with the non-Christians and "other Jewish people who are dispersed in all lands of the world" ${ }^{27}$ (HOr 82). These Jews were descendants of the people present at Christ's crucifixion who had taken the liability for his death as Matthew claims in his account of the scene. These, according to Jacques de Vitry, would have consequently lost their "appetite for combat" and would have become "weak and faint like women" as well as being "afflicted with a loss of blood" at every changing of the moon:

Finally, there are other Jews, the descendants of those who have cried out "His blood be upon us and upon our children!” [...] They are unwarlike and weak even as women, and it is said that they have a flux of blood every month. God has smitten them in their hinder

25 J. F. Hinnebusch, The Historia Occidentalis of Jacques de Vitry (Fribourg: University Press, 1972), 11.

26 Ibid., 59.

27 Jacques de Vitry, Historia Orientalis, ed. J. Donnadieu (Turnhout: Brepols, 2008), 82, 324. 
parts [Ps 78:66], and put them to perpetual opprobrium. After they slew their true brother, Abel, they were made wanderers and fugitives over the earth, cursed like Cain, with a trembling head, that is, a quaking heart, fearing both day and night, not believing in his life. $(\text { HOr } 82,160)^{28}$

We can see from this passage why Jacques' claim lies at the core of the notion of Jewish 'male menstruation,' documenting a clear conflation of theology and medicine, which shapes the image of 'the Jew' as inherently different from the predominantly Christian male majority society. It is necessary for Jacques to add that the Jewish "fluxus sanguinis" occurs monthly, like in women. Therein, he firmly establishes the connection between a particular Jewish ailment and a general physiological condition associated with the female. Evoking all the stereotypes surrounding menstruation, such as uncontrollability, physical and mental weakness, and general sinfulness resulting from Eve's original misdeed, serves as a widely accepted theological foundation for Jacques' further explications. By bringing into context not only Ps 78:66 but also Cain and Abel (Gen 4:15), Jacques clears up any doubts that the regular Jewish blood flow, like menstruation, is a divine punishment. As the Jews had spilled Christ's blood (who, typologically, is often represented by the figure of Abel), they were now condemned to suffering the regular loss of blood. All of the mentioned somatic details-the bleeding's monthly periodicity, its link to divine punishment, and Cain's restless wandering "with a trembling head"-corroborate the image of feminised and, thus, spiritually and physiologically inferior Jew. His feminine traits, both physiological and psychological with the reference to faintness and melancholia in the image of Cain's trembling head, push the Jew into a gender grey zone at the margins of Christian society. His spiritual inferiority and general 'Otherness' had become visible.

Jacques' is the only thirteenth-century description of a bleeding that recurs monthly and is linked to the lunar cycle. The popularity of his text helped convey the image of a feminised Jew. The most influential source to follow Jacques de Vitry's depiction is the Dominican Thomas de Cantimpré's Bonum Universale

28 Cited in Resnick, On Roots, 22. The original reads: "Alii autem Iudaei de quibus patres eorum clamaverunt: Sanguis eius super nos et super filios nostros [. . . ] Imbelles enim et imbecilles facti sunt quasi mulieres. Unde singulis lunationibus, ut dicitur, fluxum sanguinis patiuntur. Percussit enim eos Deus in posteriora et opprobrium sempiternum dedit illis. Postquam enim fratrem suum, verum Abel, occiderunt, facti sunt vagi et profugi super terram sicut maledictus Cain, habentes caput tremulum, id est cor pavidum, die ac nocte timentes et vite sue non credentes." Jacques de Vitry, Historia Orientalis, 328. 
de Apibus. ${ }^{29}$ For Jacques too, the Jews' bodily abjection is of divine origin, however, it is the analogy to the bleeding of female bodies which promotes a notion of impurity and shamefulness. In Christian understanding of the time, 'female' served as much as a hermeneutical category of determination as 'Jew' did. Scholastic and patristic literature had shaped a notion of women using a number of ideological mechanisms. Stereotypical traits like fragility and fickleness were attributed to the female supported and reinforced by reading of the Scripture. Exegesis of Genesis 3 and Eve's first 'sin' served as basis for the notion of female spiritual weakness and malleability and women were subsequently identified with the individual woman Eve. This resulted in an amalgamation and generalisation of spiritual character traits assigned to the female which, in turn, were claimed to be reflected also in the female body. This universalisation was thus subsequently corroborated by a naturalisation of the specific processes of a female body-menstruation, conception, and gestation. All of these processes were understood as divinely inflicted, since, again, Eve had been the first ever woman to experience all of them as a result of divine punishment. 'Natural' and 'God-given' were largely understood as synonyms. Subjection of women to men, therefore, was claimed to be a logical consequence and an equally 'natural' phenomenon.

In the case of the 'men-struating' Jew, notions of both the hermeneutical Jew and the hermeneutical woman align. Themes of alterity and aberration from a male Christian norm reflect in the motif of the bleeding body, be it Jewish or female. In both cases, the bleeding is the result of divine punishment and points to a discursive understanding of both Jews and women as spiritually inferior, hereditarily guilty, and subjected to servitude. Jacques text juxtaposes Jews and women and conflates the regular bleeding in Jewish man with (female) menstruation. Brought together with the stereotypical image of the weak woman, Jacques offers a derogatory description of the Jews that is universally applicable, grounded in authoritative theology, and can thus serve both as proof and reason for manifest legal restrictions against the Jews. ${ }^{30}$ This image also stands in a

29 Cf. J. L. Bird, "The Historia Orientalis of Jacques de Vitry: Visual and Written Commentaries as Evidence of a Text's Audience, Reception, and Utilization," Essays in Medieval Studies 20, no. 1 (2003): 58. Thomas, however, had not gone as far as to associate the regular Jewish blood flow with menstruation, as we have seen. His allusion to Matt 27:25 and a sermon by Augustine himself sufficed for Thomas to understand the bleeding ailment as proof for the Jews' hereditary guilt and spiritual inferiority.

30 Jacques wrote only a few years after the Fourth Lateran Council in 1215, which aimed at reforms, curtailing Jews' socio-political advancement and at crusade. 
sharp contrast to the normative image of Christian identity-morally and spiritually edified, and, above all, male.

\section{Naturalisation: Bernard de Gordon's Lily of Medicine (1303/5)}

The increase in 'scientific' knowledge and medical writing in urban and university contexts during the thirteenth and fourteenth century led to a translation of the 'men-struating' Jew into another theoretical sphere. Contemporary medical writing appealed largely to authoritative writings of the past and thus brought forth a corpus of texts that are also deeply rooted in theologisation. Theological tropes and doctrine powerfully influenced the pre-modern understanding of the human body and of somatic diversity. Most of the medical treatises that mention the 'men-struating' Jew consider his bleeding a natural phenomenon with natural causes. These were based on the theory of the four humours as it was developed by Hippocrates and Galen. Being hot or cold, moist or dry were the essential qualities of every body. Health depended on keeping these four humours in balance. A hot and dry body was the most desirable as it allowed food to be easily turned into bodily fluids. The qualities of heat, cold, moisture, and dryness were connected to the four humours of yellow bile, blood, phlegm, and black bile, which contributed to the formation of fluids like mucus, urine, menstrual blood, or semen. Each of these discharges was also connected to proper digestion, with semen being the most refined of bodily fluids, resulting from men's better concoction of food. Menstrual blood was also processed from food but remained less pure due to women's general cold and moist condition. Its flow out of the body served as means of purging the body of excess cold and moisture. Men who suffered from regular bleeding (usually resulting from haemorrhoids) like women, were believed to be too cold to properly digest foods. As Jews were generally believed to have a more melancholic complexion, resulting from a spicy diet and a more sedentary lifestyle, regular (haemorrhoidal) bleeding was thought to be not only common among them but most natural. ${ }^{31}$ Therefore, medical sources hardly ever describe Jewish 'male menstruation' as unclean or shameful leakage as female menstruation was. They also, mostly, do not en-

31 Cf. P. Biller, "Views of Jews from Paris around 1300: Christian or 'Scientific'?” in Christianity and Judaism: Papers Read at the 1991 Summer Meeting and the 1992 Winter Meeting of the Ecclesiastical History Society, ed. D. Wood (Oxford: Blackwell, 1992), 197-99; P. Biller, “A 'Scientific' View of Jews from Paris around 1300,” Micrologus 9 (2001): 137-68. 
gage with theological reasoning for Jewish 'male menstruation' and are more concerned with explanations grounded in practical medicine. Regardless of its physical location, the bleeding is called "fluxus sanguinis," or even simply "fluxus," and was compared to female menses. A poor diet could cause a superfluity of melancholic discharges that the body had to purge. As means of purging, haemorrhoidal and menstrual bleeding were often interchangeable in medical discussions. ${ }^{32}$ Yet, some sources paint a more colourful and a more theologically motivated and reinforced picture of Jewish 'male menstruation.' Most notably among these is Bernard de Gordon's Lily of Medicine (Lilium Medicinae).

Little is known about Bernard de Gordon's early life and education, but he became an influential teacher of medicine at the University of Montpellier between 1283 and roughly 1308. During that time he compiled the Lily of Medicine. Written between 1303 and 1305, the Lily of Medicine is a compendium of diseases with their symptoms, causes, and treatments, Bernard deals with illnesses such as scabies, splenic and pestilential fever, and leprosy. Its comprehensiveness and clarity made the Lily of Medicine "a prized encyclopedia that was aimed at giving broad access to medicine." ${ }^{33}$ It served as a standard textbook at Montpellier and Vienna universities well into the early modern times.

The compendium's seven sections follow a clear structure from a definition of the disease to its causes, symptoms, treatment, and, if questions remained, a further clarification. Such clarification appears in Bernard's discussion of the 'men-struating' Jew in his chapter on haemorrhoids and fistulae. According to Bernard, Jews

[...] suffer an immoderate flow of blood from hemorrhoids, for three reasons: generally, because they are in idleness, and for that reason the melancholic superfluities are gathered. Second, they are generally in fear and anxiety, and for this reason melancholic blood is increased, according to this [saying] of Hippocrates: "Fear and timidity, if they have a lot of time [to work], generate the melancholic humor." Third, this occurs as a divine punishment, according to [the text], "And he struck them in their posteriors and gave them over to perpetual opprobrium.” (Lily of Medicine, 5.21) ${ }^{34}$

32 Cf. e.g. Albertus Magnus, Sancti doctoris ecclesiae Alberti Magni Ordinis Fratrum Praedicatorum episcopi opera omnia, vol. 12, ed. B. Geyer (Münster: Aschendorff, 1955); or Theodoricus de Cervia, The Surgery of Theodoric: Ca A.D. 1267, ed. E. Campbell and J. Colton, 2 vols. (New York: Appleton-Century-Crofts, 1955-1960).

33 L. Demaitre, "Bernard de Gordon," in Medieval Science, Technology, and Medicine: An Encyclopedia (New York: Routledge, 2005), 85.

34 "Iudei ut plurimum patiuntur fluxum haemorrhoid. propter tria, et quia communiter sunt in ocio, et ideo congregantur superfluitates melancholicae. Secundo, quod communiter sunt in 
Bernard follows the classical Hippocratic teaching about the four humours here according to which a superfluity of the melancholic humour needs to be purged from the body by means of bleeding. Containment of these superfluous melancholic humours would result in a variety of ailments, from skin diseases to leprosy, and from dropsy to consumption. Many of these diseases were associated with the Jews, which Bernard understands as proof for his claim about the superfluity of melancholic blood in Jews. He draws on two strands of earlier scientific traditions regarding haemorrhoids and the regular bleeding resulting from them. Like many of his predecessors, Bernard traces the bleeding haemorrhoids to an accumulation of melancholic blood resulting from lack of motion and bad digestion. However, he describes the Jews' melancholic condition as arising from immobility, timidity, and a constant state of apprehension. This lifestyle, according to Bernard but following Hippocrates, resulted in an imbalance of the bodily fluids. While other medical treatises saw bleeding haemorrhoids in all men as natural, Bernard argues that the condition is natural, yet found especially in Jews as a result of divine punishment. He alludes is to Ps 78:66 and references God's punishment of the Philistines with an anal disease, commonly interpreted as haemorrhoids. While Bernard omits Matt 27:25 as the standard exegetical proof-text for the so-called "Jewish flux," the textual tradition, which we have already encountered in Jacques de Vitry's report, suggests a clear allusion here to the motif of Jewish 'male menstruation.' Thus, for Bernard, and for his readers, the Jews' haemorrhoidal bleeding was no longer a result of humoral composition alone; it was a punishment for their religious failings that had culminated in the crucifixion of Christ. We see here how theories of 'nature' intersect with theological notions. Again, as in the example of physiological processes of the female body such as menstruation, 'nature' is understood and works as a synonym for 'God-givenness.' Medical and 'scientific' underpinning however, aimed at the mechanism of naturalisation in terms of 'biologisation,' that is, connected to the human body and its functions.

Bernard de Gordon was a physician and teacher of medicine not an exegete. His text shows that a motif like Jewish 'male menstruation' reached beyond theological debate alone. Theological understandings of physiological processes were inextricably linked with medical knowledge and natural philosophical ideas of the human body and its functions. Pre-modern concepts of digestion, excretion, and reproduction had theological and physiological dimensions.

timore et anxietate, ideo multiplicatur sang. melancholicus, iuxta illud Hipp. Timor et pusilanimitas si multum tempus habuerint, melancholicum faciunt hum. Tertio quia hoc ex ultione divina, iuxta illud. Et percussit eos in posteriori dorsi, opporbrium sempiternum dedit illis." Demaitre, Doctor Bernard de Gordon, 9. 
The Lily of Medicine was widely used by medical practitioners and notions like Jewish 'male menstruation' thus moved into a medical domain. The 'menstruating' Jew gained in currency and became naturalised as a consequence. ${ }^{35}$ On the other hand, Bernard's example also demonstrates how Christianity pervaded every aspect of culture and knowledge of the period. Physicians and natural philosophers wrote on the basis of their predecessors and reiterated their theological preconceptions, stereotypes, and universalisations. Bernard's explanation for Jewish 'male menstruation' reads much like a "suppressed tautology": theological notions about Jewish somatic alterity are understood as a 'natural' phenomenon, that is both a biological and a divinely inflicted condition. This condition, in turn, is explained within a exegetical framework to support themes of Jewish hereditary guilt and inferiority. It thus "functions both as a projection onto and a lens for reading Jewish bodies as rendered inferior through the punishment and its attendant shame." ${ }^{36}$ Again, we see a parallel with female bodies punished with distinct somatic processes, like menstruation, to shame them for the 'sin' of the first woman Eve. In both examples we can also see how the mechanisms of universalisation and naturalisation intersect to support this discourse of hereditary guilt, shame, and inferiority.

\section{Normalisation: The 'Men-struating' Jew on the Iberian Peninsula}

By the end of the fifteenth century, the motif of Jewish 'male menstruation' had gained momentum in various literary contexts. The figure of the 'men-struating' Jew had entered a canon of motifs supporting the theme of Jewish 'Otherness.' The correspondence of spiritual and somatic inferiority could now be deployed also on a real and material level. Reconquista Spain serves as an example of how the motif of Jewish 'male menstruation' was employed within the discourse of blood purity, genealogical lines, and ultimately, a new understanding of race, which contributed to the normalisation of discrimination against Jews on a social, political, and legal level.

35 Cf. G. Pomata, "Menstruating Men: Similarity and Difference of the Sexes in Early Modern Medicine," in Generation and Degeneration: Tropes of Reproduction in Literature and History from Antiquity through Early Modern Europe, ed.V. Finucci and K. Brownlee (Durham: Duke University Press, 2001), 109-52.

36 Kaplan, “'His Blood Be on Us and on Our Children'," 113. 
In the course of the fifteenth century, belief in conversion and baptism declined as more Iberian Jews (and Muslims) converted to Christianity. Now that it was no longer possible to draw clear lines between community borders, means of distinguishing one from the other in terms of somatic aspects and "biological' facts became a necessity. The doctrine of "purity of blood," formalised by the Inquisition in the limpieza de sangre decrees by the end of the fifteenth century, proclaimed that "purity of faith" was manifested in the "purity of blood" and hence tried to trace back "Jewish blood" in New Christians. Following these decrees, only people with a purely "Old Christian" lineage could hold civic offices. Conversos were considered to be culturally and socially inferior and, subsequently, unclean on a 'biological' level. Their uncleanliness and inferiority was considered inherited in connection with their religious descent. 'Biological' notions and a proto-racial understanding of difference were the result of mass conversions, which "heightened anxieties of Christian identity." ${ }^{37}$ Conversos were increasingly considered an "ever-present danger to the faith, [...] which all but excluded the chance of conversion and incorporation." 38 The notion of "purity of blood" served a proto-racist construction of social identity in which the "New Christians," conversos and "Judaisers," that is, conversos who were claimed to secretly adhere to their old Jewish faith, were painted as initiators of political and social anarchy. The limpieza de sangre decrees following this ideological discourse were designed to systematically curtail the Jews' (and Muslims') social advancement and prevent the Christian majority society from purported socio-political danger. The 'men-struating' Jew figures in a number of texts from the Iberian Peninsula from the fifteenth until the seventeenth centuries with his bleeding as a sin of somatic difference and general sinfulness.

Among the first to mention the 'men-struating' Jew is Alonso de Espina in his Fortalitium Fidei of 1460. The Franciscan Catholic Bishop, preacher, and writer de Espina reflects on the reasons for ritual murder and draws back to Thomas de Cantimpré's report of 1267. He cites Thomas almost verbatim, mentioning the "stain of blood" with which Jews would be marked through all generation..$^{39}$ Conversos, who clung to their old faith, bore this sign. The Fortalitium was highly influential in discussions of conversos for centuries. In the seventeenth century, the motif was increasingly combined with legal language, seeking to create "a no-

37 Loomba, "Race and the Possibilities of Comparative Critique," 506.

38 M. Rubin, Gentile Tales: The Narrative Assault on Late Medieval Jews (New Haven: Yale University Press, 1999), 28.

39 Cf. de Espina, Fortalitium Fidei, III, cons. VII, 3:5. 
tion of 'impure blood' as referring to one's family or caste." ${ }^{40}$ Medical treatises, like in the fourteenth century, tried to bring together theological reasons and physiological explanations for Jewish 'male menstruation.' The bleeding, especially in Judaisers, would serve as a sign and revelation of their "hidden, rejected religion." 41 While in Central Europe, during the sixteenth century, medical writing had already very much distanced itself from religion, this was not the case in Iberia. In 1495, Bernard de Gordon's Lily of Medicine was translated into Castilian and provided the basis of many following claims about Jewish 'male menstruation' in the sixteenth and seventeenth centuries, again linking theological and 'scientific' theories of identity.

The 'men-struating' Jew figures most prominently in the work of Spanish court physician and jurisconsult Juan de Quiñones de Benavente (d. 1646). Following the auto-da-fé in Madrid in 1632, Quiñones issued a treatise on Jewish 'male menstruation.' Francisco de Andrada, a twenty-eight year old converso from Portugal who was convicted of Judaising, was said to suffer from a "flow of blood which nature had given to the women and which is called menstruation." ${ }^{42}$ Quiñones draws on his predecessors to provide both theological and medical reasons for Jewish bleeding. ${ }^{43}$ Jewish 'male menstruation' supported the concept of Jewish impurity and inferiority, which could not be eradicated by baptism. Quiñones concludes accordingly that "when they [sc. the Jews] are baptised, the [stain of] blood is removed and when they fall back to their errors [sc. erroneous beliefs], the ignominious stain, which they bear will return." ${ }^{44}$

Quiñones was the first to also combine the motif's theological reasoning with legal language. He lobbied for freeing the medical profession-his own-

40 J. L. Beusterien, "Jewish Male Menstruation in Seventeenth-Century Spain,” Bulletin of the History of Medicine 73, no. 3 (1999): 447.

41 Ibid., 449.

42 J. Quiñones de Benavente, Relación del auto de la fee que se celebro en la villa de Madrid Corte de su Magestad domingo quarto de Jullio de mill y seiscientos y treinta y dos años, s.a. [1632?], 1r-1v. The original Spanish reads: “[...] fue Francisco de Andrada, de quien se dixo, que padecia todos los meses el fluxo de sangre, que naturaleza dio a las mugeres, que llaman, Menstruo."

43 Julia Gebke offers a thoroughly executed close reading of Quiñones' Memorial, identifying his sources and placing it into the context of the biologisation of Christian anti-Jewish and, increasingly, proto-racist antisemitic polemic. Cf. J. Gebke, (Fremd)Körper Die Stigmatisierung der Neuchristen im Spanien der Frühen Neuzeit (Wien: Böhlau, 2019), 198-219.

44 J. de Quiñones, Memorial de Juan de Quiñones dirigido a F. Antonio de Sotomayor, Inquisidor General. Sobre el caso de Francisco de Andrada, sospechoso de pertenecer a la raza judía, discutiendo sobre los medios de conocer y perseguir a ella, s.l. s.a. [1632], 21r-21v. The original Spanish reads: "que baptizandose se les quita la sangre: y si bueluen a reincidir en sus errores, les buelue de nueuo esta infame macula que padecen." 
from conversos by accusing them of impurity of blood. Motifs like Jewish 'male menstruation' were useful in this context and were applied in inquisitorial cases. ${ }^{45}$ This general assumption of a genealogical impurity of Jewish blood was thus subsequently transferred to the social sphere of kinship and class status. This development of a cultural and 'biological' understanding of identity on the Iberian Peninsula is rooted in socio-political anxiety. Christians, Jews, and Muslims had lived next to each other in Reconquista Spain, and it was largely impossible to distinguish between members of the communities on physical terms. Visible markers of faith, such as a distorted body image, were no longer sufficient. Especially following the possibility and reality of conversion, it was necessary to find a means of distinction "that lay deeper inside." ${ }^{46}$ Religion as a cultural category of identity was now not only connected to physical appearance but came to reside within the body. As such, it could no longer be separated from it and resulted in the classification of communities, families, and individuals on an increasingly 'racial' level. Inheritance was equated with 'biology' and the processes of universalisation and naturalisation intersected to normalise and institutionalise the socio-political and socio-economic marginalisation and discrimination of these groups of people.

\section{Conclusion}

The 'men-struating' Jew serves as one example of how the ancient Christian claim of Jewish spiritual inferiority, of their hereditary guilt, and perpetual servitude were associated with a distinct somatic image beginning in the twelfth century. Theological differences were mapped onto the body to gain outward appearance and visibility. An image of 'the Jew' was created that is inherently different from the image of 'the Christian,' translating both spiritual and physiological aberrations. Somatic differences and anomalies were used as motifs to transmit the theme of Jewish 'Otherness' and serve a discourse of their overall inferiority vis-à-vis Christian superiority. This doctrine was subsequently translated into both social and legal spheres throughout pre-modern Europe. The motif of Jewish 'male menstruation' was applied in sources of various genres to support and reinforce the legal and socio-economic subjection of Jews. While images surrounding the motif of Jewish 'male menstruation' may vary according to the sources' generic intention and their authors' motivation, as we

45 Cf. Beusterien, "Jewish Male Menstruation,” 456.

46 Loomba, "Race and the Possibilities of Comparative Critique," 506. 
have seen, the motif's underlying discourse was firmly established and transported self-evidently through the ages.

An important aspect of the motif of Jewish 'male menstruation' is the cultural importance of blood. It had been promoted by theology across a range of cultural and theological narratives, from Christ's bleeding at the cross to Mary's immaculate conception, from blood lineage denoting kinship to martyrdom in battle. With regards to the 'men-struating' Jew, blood serves both as marker and binding element to reflect the Jews' heredity guilt: as they took the liability for the spilling of Christ's blood at the crucifixion, they are condemned to suffer from a similar blood loss. Evoking scriptural personae like Cain, who is marked by blood as a result of his shedding of blood, serves to corroborate the notion of the hereditary nature of Jewish servitude grounded in their spiritual inferiority.

It does not come as a surprise that the Jewish "fluxus sanguinis" was associated with menstruation. The images surrounding the motif of Jewish 'male menstruation' vary from haemorrhoidal bleeding to an uncontrollable regular purging of the body. All of these images are associated with embarrassment and shame-stereotypes that draw back to ancient Christian exegesis concerned with the female and creating a distinct image of 'women.' Its construction followed specific ideological mechanisms-stereotyping, universalising, and naturalising. The church fathers discuss women's inferior status based on their stereotypic traits such as weakness and fickleness. These topoi could easily be used as a "shaming device" 47 also for men who would not fit into the normative frame of the Christian male. We encountered this practice in Jacques de Vitry's Historia Orientalis, which explicitly associates the Jews with female weakness. The theme of women's spiritual inferiority manifested itself in the church fathers' call for the subjection of women to men, a claim which is corroborated also by their exegesis of Genesis 3. Eve's 'sin' was understood as proof for women's spiritual and mental weakness and resulted in a "limitation of women's activities and sphere of authority." ${ }^{48}$ Here, the process of universalisation becomes apparent as all women are identified with the first woman Eve and her 'weakness' and 'sinfulness'-a process very similar to the identification of the Jews present at Christ's crucifixion with all following generations who inherit their ancestors guilt. Lastly, Christian exegesis claimed that the subjection of women to men, based on their stereotypic weakness and corroborated by the amalgamation of all women to one 'woman' identified with Eve, was thus a 'natural' phenomenon.

47 E. A. Clark, “Ideology, History, and the Construction of 'Woman' in Late Ancient Christianity,” Journal of Early Christian Studies 2, no. 2 (1994): 169.

48 Ibid., 168. 
It set by the side of many other categories designating bodily necessities, such as food, sexual relations, reproduction and bodily emissions. 'Nature' often reflected back to God as the reason for and initiator of all of these matters concerning the body, sex, and gender. Menstruation as one of these processes too is Godgiven and thus 'natural,' but since it is also the result of the first 'sin' it is something shameful and impure. Jewish 'male menstruation' too is divinely inflicted and undisputable in the same way. As we have seen in Bernard de Gordon's Lily of Medicine, a 'scientific' understanding of a regular blood flow as means of purging shifted from a natural to a supernatural and, ultimately, aberrant phenomenon when linked to the idea of divine punishment. Both Jewish and female bodies are characterised subsequently by this abjection, their bleeding is now considered humiliating and shameful. It serves as an image for the transmission of the theme of alterity grounded in their spiritual inferiority.

The somatic marking of the Jews could and came to serve increasingly as a means of reinforcing theological doctrine and supporting legal and social restrictions. The example from the Iberian Peninsula showed that when the church failed to exert power over the Jews, 'scientific' narratives were developed to map the Jews' discursive inferiority onto their bodies. The limpieza de sangre decrees sought to ensure "purity of blood" in terms of blood lineage, however, the notion of kinship is clearly conflated with age-old themes of alterity and motifs of a distinct and diseased body. Rendering the Jews' inferiority visible helped to fix the ideological discourse, especially when Jews posed a threat to the Christian majority community in their social and political advancement. ${ }^{49}$ The construction of a visible identity with certain somatic features inextricably linked to it also shows, however, how alterity and diversity were understood in proto-racial terms already in pre-modern times. Based on a figural interpretation of scriptural personae such as Cain or later appearances such as the 'menstruating' Jew, a proto-racial idea was established that linked everyone nonChristian, non-white, and predominantly, non-male to notions of 'Otherness,' shamefulness, and wholesale inferiority. The discourses that had developed in theology already in late ancient times in scholastic and patristic literature

49 Kaplan has shown that as a counter-example, the 'men-struating' Jew figures less prominently in early modern English sources and links this observation to the absence of "threatening Jewish presence." Jewish communities in early modern England were hardly existent, and where Jews did dwell their communities were small in number and mostly illegal. This already subordinate position in England did not call for the need of a more distinct delineation of Jews and Christians to ensure the latter's social and legal superiority. Motifs of somatic inferiority visualising a general discourse of Jewish wholesale inferiority had thus become obsolete. Cf. Kaplan, “'His Blood Be on Us and on Our Children'," 119-22. 
were easily attached to the body and linked to further pre-modern perceptions of physiology, biological processes, and notions of sex and gender. Subsequently, they materialised in concrete images of faint women and bleeding Jewish men both of which were too weak to fulfil a proper societal role. Figural understanding as well as cultural narratives had and have multivalent possibilities. As such, they "enable the translation of hereditary inferiority from one group to another," 50 as is apparent in the case of the "men-struating' Jew where religion, race, sex and gender intersect in a polyvalent form of discrimination based on the theologically established notion of ontological inferiority.

Jewish 'male menstruation' is part of a catalogue of somatic markers of the 'Jewish' body and can be understood as one of the characteristics of the hermeneutical Jew. Authors who apply the figure of the 'men-struating' Jew do so in different variations of the motif mostly connected to their text's generic intention. Their motivation, however, is to shape, round out, and reinforce Christian identity as an identity inherently distinct from both Jews and women. While religious identity has traditionally been understood as constructed culturally, the motif of Jewish 'male menstruation' suggests that corporeal aspects served the construction as categories deeply connected with faith. It demonstrates how culture and nature are fluctuant categories and can link to shape "the (il)logic of both religious and pseudo-biological racism." 51 Theological notions of perpetual inferiority, based on hereditary guilt, work as their underpinning.

The 'men-struating' Jew can be used as an attempt to challenge ideas of purely religiously motivated Jew-hatred in pre-modern times and can help to identify proto-racial and, thus, proto-racist constructions of religious and cultural identity. Studying pre-modern sources and motifs like Jewish 'male menstruation' from this point of view can support our understanding of how racism has functioned and continues to function and how to successfully challenge, dismantle, and reject its underlying discourses.

Kerstin Mayerhofer is a PhD candidate at the University of Vienna's Institute of Jewish Studies and is co-advised at Queen Mary University of London. Her research focuses on perceptions of Jews in pre-modern Christian narrative with regards to representations of the Jewish body and gender. She has been working for the project "An End to Antisemitism!" since 2017 and has been serving as the managing editor of its multivolume conference proceedings.

50 Kaplan, Figuring Racism, 168.

51 Ibid., 4. 


\section{Bibliography}

\section{Primary Sources}

Albertus Magnus. Sancti doctoris ecclesiae Alberti Magni Ordinis Fratrum Praedicatorum episcopi opera omnia. Edited by B. Geyer. Vol. 12. Münster: Aschendorff, 1955.

Alonso de Espina. Fortalitium Fidei. Nuremberg: Aton Koberger, 1494.

Anonymous. "The Computus ludaicus of 1342." In Medieval Latin Christian Texts on the Jewish Calendar: A Study with Five Editions and Translations, edited by C. Philipp E. Nothaft, 378-477. Leiden: Brill, 2014.

Bernard de Gordon. Doctor Bernard de Gordon: Professor and Practitioner. Edited by Luke E. Demaitre. Toronto: Pontifical Institute of Mediaeval Studies, 1980.

Caesarius Heisterbacensis. Caesarii Heisterbacensis monachi ordinis Cisterciensis dialogus miraculorum. Edited by Joseph Strange. Cologne: Sumptibus J. M. Heberle, 1851.

Cecco d'Ascoli. "Cicchi esculani viri clarissimi in Spheram Mundi enarratio." In The Sphere of Sacrobosco and Its Commentators, edited by Lynn Thorndike, 343-411. Chicago: University of Chicago Press, 1949.

Hugo Cardinalis. Repertorium apostillarum utriusque testamenti domini Hugonis Cardinalis. Basel: loannes Amerbachius, loannes petri \& loannes froben, 1504.

Jacques de Vitry. Histoire orientale/Historia orientalis. Edited by Jean Donnadieu. Turnhout: Brepols, 2008.

Juan de Quiñones. Memorial de Juan de Quiñones dirigido a F. Antonio de Sotomayor, Inquisidor General. Sobre el caso de Francisco de Andrada, sospechoso de pertenecer a la raza judía, discutiendo sobre los medios de conocer y perseguir a ella. s.l. s.a. [1632?].

Juan Quiñones de Benavente. Relación del auto de la fee que se celebro en la villa de Madrid Corte de su Magestad domingo quarto de Jullio de mill y seiscientos y treinta y dos años. s.a. [1632?].

Kedar, Benjamin Z. "The Tractatus de locis et statu sancte terre ierosolimitane." In The Crusades and Their Sources: Essays Presented to Bernard Hamilton, edited by John France and William G. Zajac, 111-34. Aldershot: Ashgate, 1998.

Theodoricus de Cervia. The Surgery of Theodoric, ca. A.D. 1267. Edited by Eldrige Campbell and James Colton. 2 vols. New York: Appleton-Century-Crofts, 1955.

Thomas Cantipratanus. Bonum Universale De Apibus. Edited by G. Colvenere. Douai: Baltazar Beller, 1627.

\section{Secondary Sources}

Baron, Salo W. A Social and Religious History of the Jews. Vol. 11. 2nd rev. ed. New York: Columbia University Press, 1967.

Beusterien, John L. “Jewish Male Menstruation in Seventeenth-Century Spain.” Bulletin of the History of Medicine 73, no. 3 (1999): 447-56. 
Bildhauer, Bettina. "Blood, Jews and Monsters in Medieval Culture." In The Monstrous Middle Ages, edited by Bettina Bildhauer and Robert Millis, 75-97. Cardiff: University of Wales Press, 2003.

Bildhauer, Bettina. Medieval Blood. Cardiff: University of Wales Press, 2006.

Bildhauer, Bettina. "Medieval European Conceptions of Blood: Truth and Human Integrity: Medieval European Conceptions of Blood." Journal of the Royal Anthropological Institute 19 (2013): $57-76$.

Biller, Peter. “A 'Scientific' View of Jews from Paris around 1300.” Micrologus 9 (2001): $137-68$.

Biller, Peter. "Views of Jews from Paris around 1300: Christian or 'Scientific'?" In Christianity and Judaism: Papers Read at the 1991 Summer Meeting and the 1992 Winter Meeting of the Ecclesiastical History Society, edited by Diana Wood, 187-207. Oxford: Blackwell, 1992.

Bird, Jessalynn Lea. "The Historia Orientalis of Jacques de Vitry: Visual and Written Commentaries as Evidence of a Text's Audience, Reception, and Utilization." Essays in Medieval Studies 20, no. 1 (2003): 56-74.

Cadden, Joan. “Just Like a Woman': Passivity, Defect, and Insatiability." In Nothing Natural is Shameful: Sodomy and Science in Late Medieval Europe, 106-38. Berlin: De Gruyter, 2014.

Clark, Elizabeth A. "Ideology, History, and the Construction of 'Woman' in Late Ancient Christianity." Journal of Early Christian Studies 2, no. 2 (1994): 155-84.

Cohen, Jeremy. Living Letters of the Law: Ideas of the Jew in Medieval Christianity. Berkeley: University of California Press, 1999.

Demaitre, Luke. "Bernard de Gordon." In Medieval Science, Technology, and Medicine: An Encyclopedia, edited by Thomas F. Glick, Steven J. Livesey, and Faith Wallis, 84-85. New York: Routledge, 2005.

Diemling, Maria. “'Mit Leib und Seele?’ Überlegungen zum Körperbild jüdischer Konvertiten in der Frühen Neuzeit." Aschkenas 15, no. 2 (2006): 399-418.

Douglas, Mary. Purity and Danger: An Analysis of the Concept[s] of Pollution and Taboo. London: Routledge, 2002.

Fredriksen, Paula. "Divinity, Ethnicity, Identity: 'Religion' as a Political Category in Christian Antiquity." In Comprehending Antisemitism through the Ages: A Historical Perspective, vol. 3 of An End to Antisemitism!, ed. A. Lange, K. Mayerhofer, D. Porat, and L. H. Schiffman, 101-20. Berlin: De Gruyter, 2021.

Gaunt, Simon. Gender and Genre in Medieval French Literature. Cambridge: Cambridge University Press, 2009.

Gebke, Julia. (Fremd)Körper Die Stigmatisierung der Neuchristen im Spanien der Frühen Neuzeit. Wien: Böhlau Verlag, 2019.

Hinnebusch, John F. The Historia Occidentalis of Jacques de Vitry. Fribourg: University Press, 1972.

Isaac, Benjamin. The Invention of Racism in Classical Antiquity. Princeton: Princeton University Press, 2004.

Kaplan, M. Lindsay. Figuring Racism in Medieval Christianity. New York: Oxford University Press, 2019.

Kaplan, M. Lindsay. “'His Blood Be on Us and on Our Children': Medieval Theology and the Demise of Jewish Somatic Inferiority in Early Modern England." In The Cultural Politics of 
Blood, 1500-1900, edited by Kimberly Anne Coles, Ralph Bauer, Zita Nunes, and Carla L. Peterson, 107-26. London: Palgrave Macmillan UK, 2014.

Loomba, Ania. "Race and the Possibilities of Comparative Critique." New Literary History 40, no. 3 (2009): 501-22.

Pomata, Gianna. "Menstruating Men: Similarity and Difference of the Sexes in Early Modern Medicine." In Generation and Degeneration: Tropes of Reproduction in Literature and History from Antiquity through Early Modern Europe, edited by Valeria Finucci and Kevin Brownlee, 109-52. Durham: Duke University Press, 2001.

Prince, Gerald. A Dictionary of Narratology. Lincoln: University of Nebraska Press, 2003.

Resnick, Irven M. "Cruentation, Medieval Anti-Jewish Polemic, and Ritual Murder." Antisemitism Studies 3, no. 1 (2019): 95-131.

Resnick, Irven M. On Roots of the Myth of Jewish Male Menses in Jacques de Vitry's History of Jerusalem. Ramat Gan: Bar-Ilan University Press, 1998.

Rubin, Miri. Gentile Tales: The Narrative Assault on Late Medieval Jews. New Haven: Yale University Press, 1999.

Steinem, Gloria. "If Men Could Menstruate." In Outrageous Acts and Everyday Rebellions. New York: New American Library, 1983. 
